Floresta e Ambiente 2020; 27(1): e20171034

https://doi.org/10.1590/2179-8087.103417

ISSN 2179-8087 (online)

ORIGINAL ARTICLE - Silviculture

Floresta e Ambiente

\title{
Organic Residues and Bokashi Influence in the Growth of Alibertia edulis
}

\author{
Cleberton Correia Santos ${ }^{1}$ (D) 0000-0001-6741-2622 \\ Maria do Carmo Vieira ${ }^{1}$ (D) 0000-0001-7047-3848 \\ Néstor Antonio Heredia Zárate ${ }^{1}$ (ㄷ) 0000-0002-5070-5207 \\ Thiago de Oliveira Carnevali ${ }^{2}$ (1) 0000-0002-2577-6601 \\ Willian Vieira Gonçalves ${ }^{1}$ (D) 0000-0002-7143-9753
}

\begin{abstract}
The aim of this study was to evaluate the use of different organic residues and bokashi in the substrate formulation in the initial growth of marmelo-do-cerrado. The experiment was carried out in pots under shading (50\%). The following organic residues were tested: poultry manure (PM) with rice husk base, PM with wood shavings base, Organosuper ${ }^{\circledast}$, and castor bean meal, in a control with only soil. All treatments were assessed with and without bokashi. The experimental arrangement was a $5 \times 2$ factorial scheme in a randomized block design with four replicates and four plants. The greatest plant height was observed when the plants were cultivated in PM with rice husk base with bokashi. The pigment contents, photochemical efficiency, biomasses and quality of seedlings were highest in Organosuper ${ }^{\star}$ with bokashi. We recommend the use of Organosuper ${ }^{\varpi}$ and PM with rice husk base, both with bokashi, in the growth of marmelo-do-cerrado.
\end{abstract}

Keywords: marmelo-do-cerrado, poultry manure, Organosuper.

\section{INTRODUCTION AND OBJECTIVES}

Alibertia edulis (Rich) A. Rich. ex DC. (marmelo-do-cerrado, Rubiaceae) is a dioecious and semi-deciduous tree, native to the Cerrado region, with large leaves, white flowers, and globose berries with a fleshy sweet brown pulp (Lorenzi et al., 2006). The species is used as a food source and has forestry and medicinal properties: antidiabetic (Rieder et al., 2013), antifungal activity against Candida albicans and Cryptococcus neoformans (Silva et al., 2008), antibacterial and also leishmanicidal activities (Marques et al., 2013).

Marmelo-do-cerrado fruits are a source of food for mammals and wild birds (Oliveira et al., 2016) and can be consumed fresh or in several processed forms, including jams and jellies for humans. The plant is used in reforestation (Bento et al., 2016) for seedling plantation; thus, in situ and ex situ cultivation practices should be clearly defined.

In the cultivation practices of medicinal and forest plants, it has been shown that the addition of organic residues releases nutrients, improving physical and microbiological properties of the soil (Mangiori \& Tavares Filho, 2015), and thus increasing root soil exploration and plant growth. The forest species have a long cycle of cultivation - thus, with the gradual decomposition of organic residues, nutrients are released favoring growth and development.

Among the possible organic residues, poultry manure is widely available in several Brazilian states owing to the development of the poultry industry. Globally, Brazil is the largest exporter of chicken meat; the number of poultry produced in 2015 was 5.79 billion (IBGE, 2015). As each bird produces approximately $1.8 \mathrm{~kg}$ of residue (Rogeri et al., 2016), the production of poultry manure is estimated to be $10.450 \mathrm{t}_{\text {year }}{ }^{-1}$.

Poultry manure is characterized by a high nutrient content, low decomposition rate, and conditioning effect when added to the soil; it is therefore a viable alternative in the nutritional dynamics of the soil, mainly because it contains nitrogen in the organic fraction (Eguchi et al., 2016; Rogeri et al., 2016), which favors the use of nutrients by plants during the growth cycle.

Species native to the Cerrado region generally respond positively to the addition of poultry manure to the growth substrate. For instance, the emergence and length of the aerial part $(20.07 \mathrm{~cm})$ of Eugenia pyriformis Cambess. improved

\footnotetext{
${ }^{1}$ Universidade Federal da Grande Dourados (UFGD), Dourados, MS, Brasil
}

${ }^{2}$ Universidade Federal do Pará (UFPA), Altamira, PA, Brasil 
with the use of Dystroferric Red Latosol, sand, and poultry manure, in the ratio 1:2:0.5 $(\mathrm{v} / \mathrm{v})$, when the field capacity was maintained at $100 \%$ (Scalon \& Jeromine, 2013).

Another option is Organosuper ${ }^{\oplus}$, an organomineral compound used in organic farming. After the treatment of medicinal plants with Organosuper ${ }^{\bullet}$, noteworthy changes were observed for Campomanesia xanthocarpa O. Berg. - the length of the aerial part $(29.59 \mathrm{~cm})$ was longer when cultivated in Dystroferric Red Latosol, sand, and Organosuper ${ }^{\circ}(5: 4: 1 \mathrm{v} / \mathrm{v})$ (Carnevali et al., 2015).

Bokashi is a balanced blend of organic matter of vegetable and/or animal origin subjected to a fermentation process controlled by favorable microorganisms (Baldotto \& Baldotto, 2016). The agricultural effects of bokashi are associated with increased cation exchange capacity, soil $\mathrm{pH}$ and faster availability of nutrients (Boechat et al., 2013).

To our knowledge, no studies have focused on the effects of organic residues on marmelo-do-cerrado. Thus, the aim of the study here presented was to evaluate the effect of different organic residues, with and without the addition of bokashi, and to recommend a substrate for the initial growth of marmelo-do-cerrado.

\section{MATERIALS AND METHODS}

The study was performed between January and August 2015 in a protected environment (nursery) (22 11'43.7'S and $54^{\circ} 56^{\prime} 08.5^{\prime \prime} \mathrm{W}, 452 \mathrm{~m}$ ), with a $150-\mu \mathrm{m}$ transparent polyethylene top cover and additional black screen shade protection on the sides and top, provided $50 \%$ retention of the solar radiation and a photosynthetic radiation average of $924 \mu \mathrm{mol} \mathrm{m}^{-2} \mathrm{~s}^{-1}$.

The seeds used were randomly collected from fruits of marmelo-do-cerrado (Authorization of Access and Sample Shipping of Genetic Heritage Component No. 010220/20151 - CNPq/CGEN/MMA) in the Cerrado region (18 $07^{\circ} 03^{\prime \prime}$, $54^{\circ} 25^{\prime} 07^{\prime \prime} \mathrm{W}, 452 \mathrm{~m}$ ). The species was identified and an exsiccate was deposited in the Dourados, State of Mato Grosso do Sul (DDMS) herbarium, Federal University of Grande Dourados (nº.4649).

To obtain the seedlings, mature fruits were pulped by hand; the seeds were then selected, washed in running water, and immersed in 1\% sodium hypochlorite for $5 \mathrm{~min}$. After this, they were put in 128-cell expanded polystyrene trays with Bioplant ${ }^{\oplus}$ substrate.

The treatments used soil combined with the following organic residues: $\mathrm{PMH}$, semi-decomposed poultry manure with rice husk base (4.16 $\left.\mathrm{g} \mathrm{kg}^{-1}\right)$; PMW, semi-decomposed poultry manure with wood shavings base $\left(4.16 \mathrm{~g} \mathrm{~kg}^{-1}\right)$; ORG, Organosuper ${ }^{\circledR}\left(4.16 \mathrm{~g} \mathrm{~kg}^{-1}\right)$; CBM, castor bean meal $\left(0.83 \mathrm{~g} \mathrm{~kg}^{-1}\right)$; and the control (soil only). Treatments were tested without and with the addition of Garden Bokashi ${ }^{\oplus}\left(80 \mathrm{~g} \mathrm{pot}^{-1}\right)$, into four applications. The chemical composition of the organic residues is in Table 1. The experimental arrangement was a 5 $\times 2$ factorial scheme in a randomized block design with four replicates. The experimental unit comprised four plastic pots $\left(4.2 \mathrm{dm}^{3}\right)$ and one plant per pot.

Table 1. Chemical composition of the organic residues used in the experiment.

\begin{tabular}{|c|c|c|c|c|c|c|c|c|}
\hline \multirow{2}{*}{$\begin{array}{l}\text { Organic } \\
\text { residues }\end{array}$} & pH & $\mathrm{C}^{3}$ & $\mathbf{N}$ & $\mathbf{P}$ & K & $\mathrm{Ca}$ & $\mathrm{Mg}$ & $\mathrm{C} / \mathrm{N}^{4}$ \\
\hline & $\mathrm{CaCl}_{2}$ & \multicolumn{7}{|c|}{$\mathrm{g} \mathrm{kg}^{-1}$} \\
\hline $\begin{array}{l}\text { Poultry } \\
\text { manure }^{1}\end{array}$ & 6.4 & 267.0 & 26.6 & 21.4 & 11.0 & 38.1 & 11.6 & $10 / 1$ \\
\hline $\begin{array}{l}\text { Poultry } \\
\text { manure }\end{array}$ & 6.2 & 291.0 & 15.8 & 15.3 & 16.8 & 19.3 & 8.5 & $18 / 1$ \\
\hline Organosuper & 8.0 & 1210.0 & 67.0 & 43.0 & 4.0 & 27.0 & 4.0 & $18 / 0$ \\
\hline $\begin{array}{l}\text { Castor bean } \\
\text { meal }\end{array}$ & 6.1 & 840.0 & 14.0 & 3.0 & 45.0 & 7.0 & 4.0 & $60 / 1$ \\
\hline $\begin{array}{l}\text { Garden } \\
\text { Bokashi }^{\oplus}\end{array}$ & 6.1 & 400.0 & 34.0 & 8.0 & 7.0 & 22.0 & 5.0 & $11 / 1$ \\
\hline
\end{tabular}

${ }^{1}$ Rice husk base; ${ }^{2}$ Wood shavings base; ${ }^{3}$ Organic carbon; ${ }^{4} \mathrm{C} / \mathrm{N}$ ratio.

The soil used for filling the pots was Dystroferric Red Latosol with clay texture (Santos et al., 2013), which had the following chemical properties (Silva, 2009): $\mathrm{pH} \mathrm{CaCl}_{2}=4.3$; $\mathrm{P}=1.7 \mathrm{mg} \mathrm{dm}{ }^{-3} ; \mathrm{Ca}=6.7 \mathrm{mmol}_{\mathrm{c}} \mathrm{dm}^{-3} ; \mathrm{K}=4.0 \mathrm{mmol}_{\mathrm{c}} \mathrm{dm}^{-3}$; $\mathrm{Mg}=1.8 \mathrm{mmol}_{c} \mathrm{dm}^{-3} ; \mathrm{Al}=1.2 \mathrm{mmol} \mathrm{dm}_{c} ; \mathrm{H}+\mathrm{Al}=29.9 \mathrm{mmol} \mathrm{dm}_{c}^{-3} ;$ $\mathrm{SB}=12.9 \mathrm{mmol}_{\mathrm{c}} \mathrm{dm}^{-3} ; \mathrm{T}=42.4 \mathrm{mmol}_{\mathrm{c}} \mathrm{dm}^{-3}$, and $\mathrm{V} \%=29.5$. Soil liming was performed 30 days before transplantation using dolomite limestone filler with $80 \%$ PRNT (manually incorporated) with the aim of achieving $60 \%$ base saturation. Samples were then taken from the substrates for chemical analysis (Silva, 2009) (Table 2).

Table 2. Chemical composition of the substrates used in the experiment.

\begin{tabular}{|c|c|c|c|c|c|c|c|c|c|}
\hline \multirow{2}{*}{ Treatments } & pH & $\mathbf{P}$ & $\mathbf{K}$ & $\mathrm{Ca}$ & Mg & $\mathbf{H}+\mathbf{A l}$ & SB & $\mathrm{T}$ & V \\
\hline & $\mathrm{CaCl}_{2}$ & $\mathrm{mg} \mathrm{dm}^{-3}$ & \multicolumn{6}{|c|}{ mmolc dm-3 } & $\%$ \\
\hline \multicolumn{10}{|c|}{ Without bokashi } \\
\hline PMH & 6.26 & 45.55 & 9.68 & 5.04 & 6.55 & 3.27 & 11.97 & 15.11 & 70.54 \\
\hline PMW & 6.35 & 36.60 & 7.87 & 5.47 & 6.72 & 3.09 & 12.73 & 15.80 & 72.44 \\
\hline ORG & 6.55 & 36.30 & 7.90 & 5.62 & 5.31 & 3.34 & 10.97 & 14.24 & 68.01 \\
\hline CBM & 6.21 & 26.48 & 5.71 & 4.70 & 5.56 & 2.98 & 10.72 & 13.45 & 69.32 \\
\hline Soil & 6.75 & 5.8 & 1.33 & 3.37 & 4.52 & 2.30 & 8.56 & 10.45 & 69.17 \\
\hline
\end{tabular}


Table 2. Continued...

\begin{tabular}{|c|c|c|c|c|c|c|c|c|c|}
\hline \multirow{2}{*}{ Treatments } & pH & $\mathbf{P}$ & K & $\mathrm{Ca}$ & $\mathrm{Mg}$ & $\mathbf{H}+\mathbf{A l}$ & SB & $\mathbf{T}$ & V \\
\hline & $\mathrm{CaCl}_{2}$ & $\mathrm{mg} \mathrm{dm}^{-3}$ & \multicolumn{6}{|c|}{ mmolc dm-3 } & $\%$ \\
\hline \multicolumn{10}{|c|}{ With bokashi } \\
\hline PMH & 6.25 & 52.60 & 11.08 & 5.76 & 7.50 & 3.34 & 13.46 & 16.76 & 71.88 \\
\hline PMW & 6.43 & 48.07 & 10.36 & 3.84 & 4.62 & 2.53 & 9.24 & 11.47 & 61.08 \\
\hline ORG & 6.38 & 48.00 & 10.38 & 4.87 & 5.35 & 2.77 & 10.45 & 13.03 & 71.89 \\
\hline CBM & 6.20 & 24.89 & 5.42 & 5.26 & 7.19 & 3.29 & 12.85 & 16.05 & 71.89 \\
\hline Soil & 6.77 & 19.92 & 3.25 & 3.63 & 5.50 & 2.54 & 9.73 & 11.88 & 70.71 \\
\hline
\end{tabular}

PMH: poultry manure with rice husk base; PMW: poultry manure with wood shavings base; ORG: Organosuper ; CBM: castor bean meal.

Transplantation to the pots was carried out 60 days after sowing, when the seedlings had a mean height of $5 \mathrm{~cm}$. Cultivation treatments included daily irrigation, uprooting of spontaneous plants, and pest control. One hundred days after transplant (DAT) there was an incidence of aphids, cochineal, and whitefly. Effective control was achieved through two sprays with neem oil (Azadirachta indica A. Juss.) at 3\% and vegetable oil at $5 \%$.

During the crop cycle, the plant height, number of leaves, and collar diameter were evaluated every 30 days from 60 to 150 DAT. The height of the plants was defined as the distance between the collar and the inflection of the highest leaf. The stem diameter was placed $\pm 1.0 \mathrm{~cm}$ above the substrate level and the number of leaves was manually counted.

After 150 DAT, the initial $\left(\mathrm{F}_{0}\right)$ and maximum $\left(\mathrm{F}_{\mathrm{m}}\right)$ chlorophyll $a$ fluorescence emissions were quantified using a portable fluorometer (OS $p 30$; OPTI-SCIENCES) after the leaves were kept in the dark for 30 min using leaf clips and under a flash of $1.500 \mu \mathrm{mol} \mathrm{m}^{-2} \mathrm{~s}^{-1}$; the variable "fluorescence $\left(\mathrm{F}_{\mathrm{v}}\right.$ )" was calculated as the difference between $\mathrm{F}_{0}$ and $\mathrm{F}_{\mathrm{m}}$. The photochemical quantum efficiency of the photosystem II (PS II) $\left(\mathrm{F}_{\mathrm{v}} / \mathrm{F}_{\mathrm{m}}\right)$ and the effective energy conversion efficiency $\left(\mathrm{F}_{\mathrm{v}} / \mathrm{F}_{0}\right)$ were calculated from the data obtained.

The content of chlorophyll $a$, chlorophyll $b$, total chlorophyll, and carotenoids were quantified at $150 \mathrm{DAT}$, and a fully expanded leaf blade was collected from each plant. A sample ( $1 \mathrm{~g})$ was weighed and macerated with a pestle and mortar in $8 \mathrm{~mL} 80 \%$ acetone. Subsequently, the solutions were centrifuged at $1500 \mathrm{rpm}$ for $10 \mathrm{~min}$. The absorbance was read at wavelengths of 470,645 , and $663 \mathrm{~nm}$ using a spectrophotometer. The concentrations of chlorophyll and carotenoids were calculated in accordance with Arnon (1949) and Lichtenthaler \& Buschmann (2001), respectively.

At 155 DAT, plants were withdrawn from the pots, washed, and had their leaves, stems, and roots separated. To obtain the dry mass, the samples were packed in Kraft paper bags and placed in a greenhouse with forced air ventilation at $60 \pm 5{ }^{\circ} \mathrm{C}$, until a constant mass was reached. The samples were weighed on a precision balance $( \pm 0.0001 \mathrm{~g})$. The leaf and root surface areas were determined using the area integrator LI-COR 3100 C. The leaf area ratio, specific leaf area, and specific leaf mass were calculated by assessing the dry mass and leaf area (Benincasa, 2003). The Dickson quality index (DQI) (Dickson et al., 1960) was also calculated.

Analysis of variance was conducted on the average values and the data were analyzed at the $5 \%$ probability level by using the F-test. The data evaluated during the cultivation cycle were analyzed using subdivisions of time; when significance was determined in the F-test, the averages were submitted to regression analysis as a function of the number of days of the cycle. The data obtained on the mass production, physiological indices, and quality of seedlings were analyzed as a factorial, and when significant, the averages were compared using Student's t-test and Tukey's test for bokashi and the organic residues, respectively, at the $5 \%$ probability level.

\section{RESULTS AND DISCUSSION}

The plants were taller with the addition of bokashi, regardless of the substrate (Figure 1a), when compared without the use of bokashi. For the organic residues, the maximum height was $27.33 \mathrm{~cm}$ at 150 DAT in the plants grown in PMH with bokashi. The increased height of marmelo-do-cerrado plants grown in the substrate soil and poultry manure with wood shavings as the base and with bokashi might be related to the greater use of nutrients (Tables 1 and 2) by the plants (Baldotto \& Baldotto, 2016). Without bokashi, there was little variation of plant growth in the substrates (Figure 1b).

The $\mathrm{PMH}$, owing to the lower $\mathrm{C} / \mathrm{N}$ ratio, underwent the fastest mineralization resulting in subsequent faster nutrient delivery to the plants (Peixoto Filho et al., 2013). Furthermore, the addition of bokashi resulted in an increase of favorable microorganisms in the substrate that may have accelerated the cycling and availability of nutrients; as bokashi contains nitrogen fixers, the availability of $\mathrm{N}$ and other nutrients increased (Álvares-Solís et al., 2016).

The largest stem diameters were 3.42 and $3.30 \mathrm{~mm}$ in plants grown in PMH and in ORG, both with bokashi, respectively, at 150 DAT (Figure 2a). In contrast, the largest stem diameter in the absence of bokashi was $2.84 \mathrm{~mm}$ in the substrate with only soil (Figure $2 \mathrm{~b}$ ). The highest number of leaves was 21 leaves/plant, which was found in plants grown in $\mathrm{PMH}$; the next highest number (18 leaves/plant) was found in plants grown in ORG, regardless of bokashi (Figure 2c).

The larger stem diameters observed in the plants grown in the substrates, both with bokashi, allowed greater development of the root system, which reduced the time required for the seedlings to be transplanted to the field (Campos \& Uchida, 2002). 

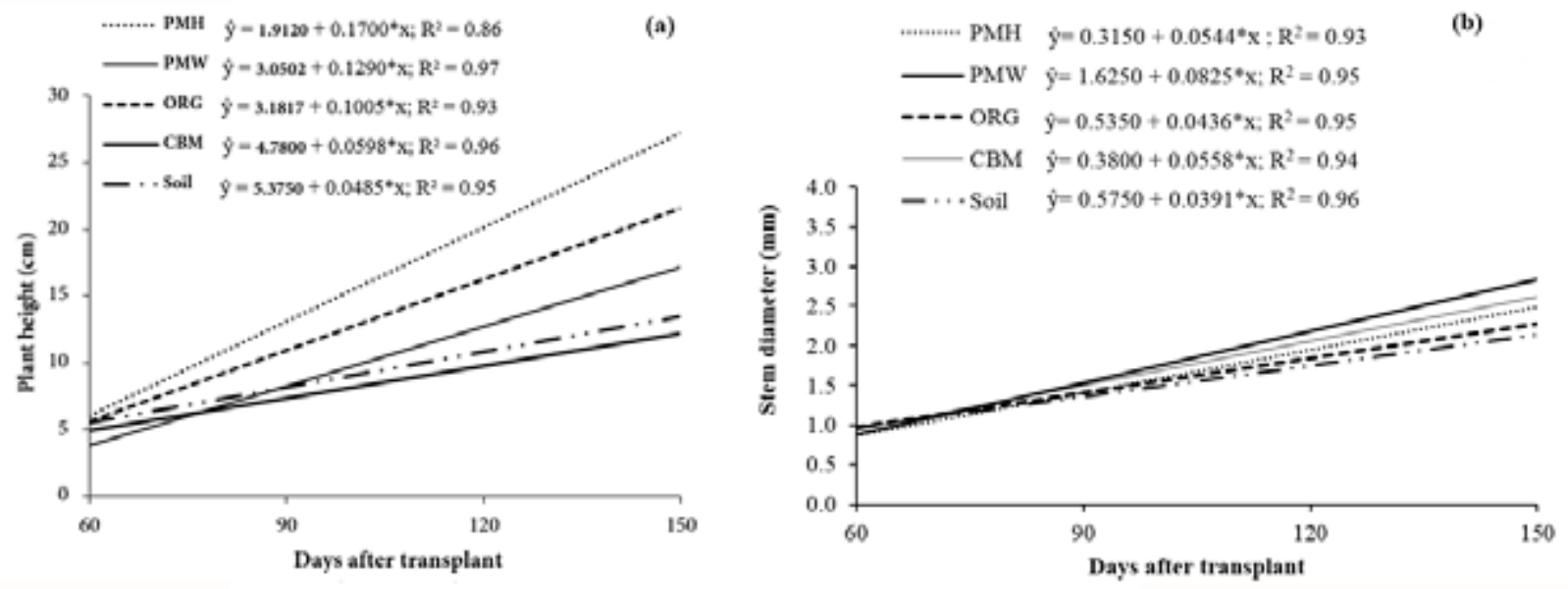

PMH: poultry manure with rice husk base; PMW: poultry manure with wood shavings base; ORG: Organosuper ${ }^{\circledR}$; CBM: castor bean meal.

Figure 1. Height of plants of marmelo-do-cerrado cultivated in pots with organic residues (a) with and (b) without bokashi as a function of evaluation times.
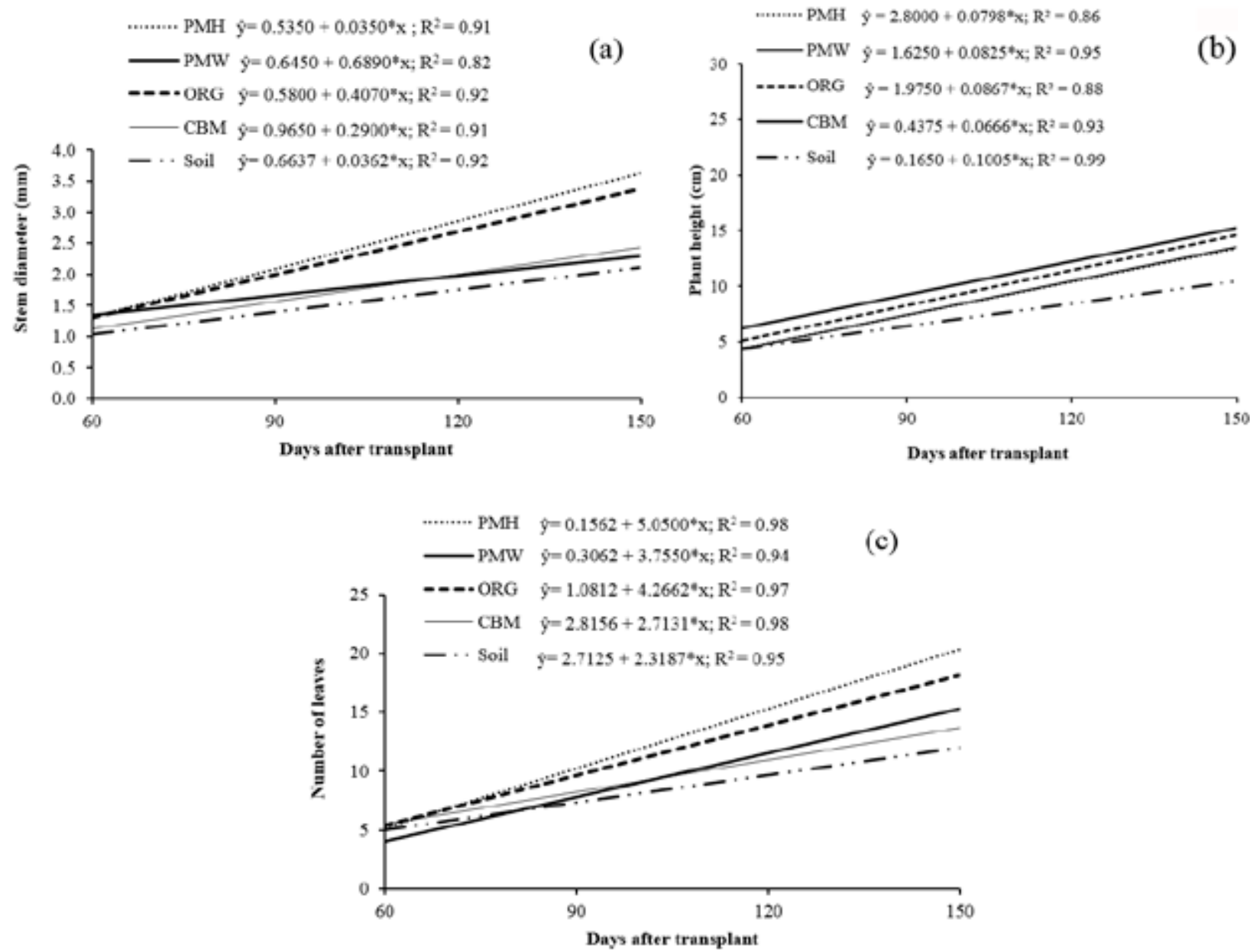

PMH: poultry manure with rice husk base; PMW: poultry manure with wood shavings base; ORG: Organosuper; CBM: castor bean meal. Figure 2. Diameter stem (a) with, (b) without bokashi and (c) number of leaves of marmelo-do-cerrado cultivated in pots with organic residues as a function of evaluation times. 
The increased number of leaves in the plants grown in $\mathrm{PMH}$, followed by that in plants cultivated with ORG, was attributable to the higher content of nutrients, including nitrogen, present in these organic residues (Table 1). Nitrogen was found in the organic fraction of the poultry manure (Bolan et al., 2010), which stimulated more vigorous growth and prolonged the vegetative period (Ghorbani et al., 2008).

The highest levels of chlorophyll $a$ were observed in the leaves of the plants cultivated in PMH, PMW, and ORG, all with bokashi (Table 3); chlorophyll $b$ in ORG, with bokashi, and total chlorophyll in ORG, with bokashi and $\mathrm{PMH}$, without and with bokashi. In addition, the increased levels of chlorophylls in the plants grown in PMH or ORG, both with bokashi, may be associated with the nutrient content of their chemical composition, especially magnesium (Table 2), which is part of the chlorophyll molecule (Taiz \& Zeiger, 2013).

The highest chlorophyll $a / b$ ratio was observed in plants grown in CBM with bokashi, differing only PMH, PMW and ORG, without bokashi (Table 4). The highest carotenoid contents were in PMH and ORG, both with bokashi. The increase in the carotenoids levels in these same substrates is a favorable response, as it minimizes possible photo-oxidative damage (Streit et al., 2005) and enhances the use of chlorophyll $a$ in the photosynthesis.

The initial and maximum fluorescence emissions were not influenced by the factors under study (Table 5). The initial or maximum chlorophyll $a$ fluorescence emissions were not significantly influenced by the substrates, as marmelo-docerrado belongs to an ecological group of non-pioneer species (Leles et al., 2011), which remain in shaded places with low luminosity (Calegari et al., 2011), favored in the cultivation environment with a $50 \%$ shading screen.

The other photochemical characteristics were influenced only by organic residues (Table 5 ). The potential quantum efficiency of the PS II $\left(\mathrm{F}_{\mathrm{v}} / \mathrm{F}_{\mathrm{m}}\right)$ of the leaves of the marmelodo-cerrado was higher when cultivated in the $\mathrm{PMH}$, differing statistically from PMW only (Table 5); consequently, the effective efficiency of the absorbed energy conversion $\left(\mathrm{F}_{\mathrm{v}} / \mathrm{F}_{0}\right)$ was similar, most likely owing to the higher nutrient content in the substrate (Table 2 ), especially phosphorus, magnesium and nitrogen present in organic residues (Table 1). Phosphorus acts as a source of energy in the electron transport (Veigas et al., 2013), increasing the efficiency of the leaves in the conversion of absorbed energy $\left(\mathrm{F}_{\mathrm{v}} / \mathrm{F}_{0}\right)$, which was consistent with an increase in $\mathrm{F}_{\mathrm{v}}$ associated with electron transferability.

The $\mathrm{F}_{\mathrm{v}} / \mathrm{F}_{\mathrm{m}}$ ratio quantified the potential quantum efficiency of the PS II, which is an important characteristic in the analysis of plant growth, as it estimates the ability of leaves to absorb energy when adapted to the dark (Murchie \& Lawson, 2013), and determines the cultivation conditions under which these parameters are more synchronized.We found the lower efficiency values of PS II in the leaves of the plants grown cultivated with PMW, since wood shavings are a highly fibrous material with a slow decomposition rate (Table 1). Thus, the nutrients involved in the photochemical process may have been released in smaller amounts throughout the crop when compared with other organic residues, which reduced the efficiency of electron transport between the receptors in the photosystems.

The plants with the largest leaf and root areas were those grown in PMH and ORG, both with bokashi (Table 6). The highest leaf area of the plants grown in substrates was related to the higher chlorophyll $a$ content, which is associated with the quantum efficiency of PS II. Subsequently, this provided better conditions for photosynthetic conversion and an increase in photoassimilates for the expansion of the leaf limbs.

The response to organic residues varies among species. The seedlings of Campomanesia xanthocarpa O. Berg showed higher growth in pots with substrates based on organic residues and greater leaf area $\left(167.90 \mathrm{~cm}^{2}\right)$ in a substrate containing dystroferric Red Latosol, sand, and Organosuper ${ }^{\circ}$ $(5: 4: 1, \mathrm{v} / \mathrm{v})$ (Carnevali et al., 2015). For seedlings of Eugenia pyriformis Cambess., the largest leaf areas were obtained after the addition of poultry manure (Scalon \& Jeromine, 2013), which was also observed in our study.

The larger root area gains were attributed to the addition of organic residues and resulted in a possible improvement in the physical properties of the substrate, such as moisture retention, aeration and lower compaction (Valadão et al., 2011), which have favored root development and expansion. Thus, when added to soil with a mean density of $1.2 \mathrm{dm}^{3}$, these semi-decomposed residues with a density of $0.4-0.6 \mathrm{dm}^{3}$ (Kiehl, 2008) lowered the substrate density, resulting in a conditioning effect (Eguchi et al., 2016).

The highest dry masses of leaves and roots were observed in the plants grown in PMH or ORG with bokashi (Table 7). The higher mass yields resulted from, among other factors, the substrate nutrients, such as phosphorus (Table 2), which helps to define the amount of biomass (Vieira et al., 2015) by participation in cell differentiation (Taiz \& Zeiger, 2013).

When plants have larger leaf areas, the solar energy retention capacity is higher, which causes an increase in photoassimilates and mass production (González-Sanpedro et al., 2008), as observed in this study. The addition of organic residues improved the physical properties of the soil, increasing the retention and availability of water and reducing the resistance to root penetration (Mosaddeghi et al., 2009). 
Table 3. Chlorophyll content $a, b$ and total leaves of marmelo-do-cerrado cultivated in pots with soil, organic residues, and bokashi (B).

\begin{tabular}{|c|c|c|c|c|c|c|}
\hline \multirow{2}{*}{ Residues } & \multicolumn{2}{|c|}{ Chlorophyll $a\left(\mu \mathrm{g} \mathrm{cm}^{2}\right)$} & \multicolumn{2}{|c|}{ Chlorophyll $b\left(\mu \mathrm{g} \mathrm{cm}^{2}\right)$} & \multicolumn{2}{|c|}{ Total chlorophyll $\left(\mu \mathrm{g} \mathrm{cm}^{2}\right)$} \\
\hline & $-\mathbf{B}$ & $+B$ & $-\mathbf{B}$ & $+B$ & $-\mathbf{B}$ & $+B$ \\
\hline PMH & $27.56 \mathrm{aB}$ & $28.65 \mathrm{aA}$ & $18.52 \mathrm{aA}$ & $16.15 \mathrm{bB}$ & $46.09 \mathrm{aA}$ & $44.80 \mathrm{abA}$ \\
\hline PMW & $23.13 \mathrm{bB}$ & $25.74 \mathrm{aA}$ & $11.89 \mathrm{bB}$ & $15.35 \mathrm{bA}$ & $35.03 \mathrm{bB}$ & $41.09 \mathrm{bA}$ \\
\hline ORG & $16.61 \mathrm{cB}$ & $25.84 \mathrm{aA}$ & $11.87 \mathrm{bB}$ & $21.08 \mathrm{aA}$ & $28.49 \mathrm{cB}$ & $46.92 \mathrm{aA}$ \\
\hline CBM & $16.73 \mathrm{cA}$ & $13.74 \mathrm{bB}$ & $10.14 \mathrm{bA}$ & $5.35 \mathrm{cB}$ & $26.88 \mathrm{cA}$ & $19.09 \mathrm{cB}$ \\
\hline Soil & $21.40 \mathrm{bA}$ & $15.02 \mathrm{bB}$ & $11.70 \mathrm{bA}$ & $7.29 \mathrm{cB}$ & $33.11 \mathrm{bA}$ & $22.31 \mathrm{cB}$ \\
\hline C.V. (\%) & & & & & & \\
\hline
\end{tabular}

PMH: poultry manure with rice husk base; PMW: poultry manure with wood shavings base; ORG: Organosuper; CBM: castor bean meal. Averages followed by lower case letters equal, in the columns, for residues and upper case in the lines, for bokashi, do not differ between them, by Tukey's test and Student's t-test, respectively, at $5 \%$.

Table 4. Chlorophyll $a / b$ ratio and carotenoid content of marmelo-do-cerrado leaves cultivated in pots with soil, organic residues, and bokashi (B).

\begin{tabular}{|c|c|c|c|c|}
\hline & \multicolumn{2}{|c|}{$a / b\left(\mu \mathrm{g} \mathrm{cm}^{2}\right)$} & \multicolumn{2}{|c|}{ Carotenoids $\left(\mu \mathrm{g} \mathrm{cm}^{2}\right)$} \\
\hline Organic residue & $-\mathbf{B}$ & $+\mathbf{B}$ & $-\mathbf{B}$ & $+\mathbf{B}$ \\
\hline Poultry manure with rice husk base & $1.49 \mathrm{aA}$ & $1.77 \mathrm{bcA}$ & $12.27 \mathrm{aB}$ & $13.14 \mathrm{aA}$ \\
\hline Poultry manure with wood shavings base & $1.96 \mathrm{aA}$ & $1.69 \mathrm{bcA}$ & $9.43 \mathrm{bB}$ & $11.56 \mathrm{bA}$ \\
\hline Organosuper & $1.43 \mathrm{aA}$ & $1.23 \mathrm{cA}$ & $8.80 \mathrm{bB}$ & $12.98 \mathrm{aA}$ \\
\hline Castor bean meal & $1.65 \mathrm{aB}$ & $2.62 \mathrm{aA}$ & $8.28 \mathrm{bA}$ & $5.62 \mathrm{~dB}$ \\
\hline Soil & $1.82 \mathrm{aA}$ & $2.19 \mathrm{abA}$ & $9.44 \mathrm{bA}$ & $7.50 \mathrm{cB}$ \\
\hline C.V. (\%) & \multicolumn{2}{|c|}{16.91} & \multicolumn{2}{|c|}{5.96} \\
\hline
\end{tabular}

Averages followed by lower case letters equal, in the columns, for residues and upper case in the lines, for bokashi, do not differ between them, by Tukey's test and Student's t-test, respectively, at $5 \%$.

Table 5. Initial $\left(\mathrm{F}_{0}\right)$, maximum $\left(\mathrm{F}_{\mathrm{m}}\right)$ and variable $\left(\mathrm{F}_{\mathrm{v}}\right)$ fluorescence; photochemical efficiency of the photosystem II $\left(\mathrm{F}_{\mathrm{v}} / \mathrm{F}_{\mathrm{m}}\right)$ and effective energy conversion efficiency $\left(\mathrm{F}_{\mathrm{v}} / \mathrm{F}_{0}^{\mathrm{m}}\right)$ of leaves of marmelo-do-cerrado cultivated in pots with soil and organic residues.

\begin{tabular}{lccccc} 
& $F_{0}$ & $F_{m}$ & $F_{v}$ & $F_{v} / F_{m}$ & \\
\hline Organic residue & & & $F_{v} / F_{0}$ & \\
PMH & $0.258 \mathrm{a}$ & $0.977 \mathrm{a}$ & $0.745 \mathrm{a}$ & $0.731 \mathrm{a}$ & $2.905 \mathrm{a}$ \\
PMW & $0.315 \mathrm{a}$ & $0.835 \mathrm{a}$ & $0.570 \mathrm{~b}$ & $0.612 \mathrm{~b}$ & $2.008 \mathrm{~b}$ \\
ORG & $0.312 \mathrm{a}$ & $0.881 \mathrm{a}$ & $0.620 \mathrm{ab}$ & $0.675 \mathrm{ab}$ & $2.018 \mathrm{~b}$ \\
CBM & $0.260 \mathrm{a}$ & $0.833 \mathrm{a}$ & $0.573 \mathrm{~b}$ & $0.677 \mathrm{ab}$ & $2.405 \mathrm{ab}$ \\
Soil & $0.297 \mathrm{a}$ & $0.902 \mathrm{a}$ & $0.547 \mathrm{~b}$ & $0.669 \mathrm{ab}$ & $1.957 \mathrm{~b}$ \\
C.V. (\%) & 22.57 & 18.69 & 19.11 & 11.16 & 23.74
\end{tabular}

PMH: poultry manure with rice husk base; PMW: poultry manure with wood shavings base; ORG: Organosuper; CBM: castor bean meal. Averages followed by equal letters in the columns do not differ by Tukey's test for organic residues at $5 \%$.

Table 6. Leaf and root surface area of marmelo-do-cerrado cultivated in pots with soil, organic residues, and bokashi (B).

\begin{tabular}{|c|c|c|c|c|}
\hline & \multicolumn{2}{|c|}{ Leaf area $\left(\mathrm{cm}^{2}\right.$ plant $\left.^{-1}\right)$} & \multicolumn{2}{|c|}{ Root area $\left(\mathrm{cm}^{2}\right.$ plant $\left.^{-1}\right)$} \\
\hline Organic residue & $-\mathbf{B}$ & $+\mathbf{B}$ & $-\mathbf{B}$ & $+B$ \\
\hline Poultry manure with rice husk base & $132.87 \mathrm{abB}$ & $250.45 \mathrm{aA}$ & $16.33 \mathrm{aB}$ & $22.13 \mathrm{aA}$ \\
\hline Poultry manure with wood shavings base & $145.35 \mathrm{aB}$ & $192.53 \mathrm{bA}$ & $14.95 \mathrm{aA}$ & $10.96 \mathrm{bA}$ \\
\hline Organosuper $^{\oplus}$ & $73.12 \mathrm{cdB}$ & $224.31 \mathrm{aA}$ & $9.82 \mathrm{abB}$ & $22.52 \mathrm{aA}$ \\
\hline Castor bean meal & $103.34 \mathrm{bcA}$ & $76.24 \mathrm{bB}$ & $11.96 \mathrm{abA}$ & $11.87 \mathrm{bA}$ \\
\hline Soil & $59.81 \mathrm{dA}$ & $66.29 \mathrm{bA}$ & $7.05 \mathrm{bB}$ & $12.83 \mathrm{bA}$ \\
\hline C.V. (\%) & \multicolumn{2}{|c|}{12.41} & \multicolumn{2}{|c|}{24.84} \\
\hline
\end{tabular}

Averages followed by lower case letters equal, in the columns, for residues and upper case in the lines, for bokashi, do not differ between them, by Tukey's test and Student's t-test, respectively, at $5 \%$.

Table 7. Dry mass of leaves, stems and roots of marmelo-do-cerrado cultivated in pots with soil, organic residues, and bokashi (B).

\begin{tabular}{|c|c|c|c|c|c|c|}
\hline \multirow{3}{*}{ Residues } & \multicolumn{6}{|c|}{ Dry mass (g plant $\left.{ }^{-1}\right)$} \\
\hline & \multicolumn{2}{|c|}{ Leaves } & \multicolumn{2}{|c|}{ Stems } & \multicolumn{2}{|c|}{ Roots } \\
\hline & $-\mathbf{B}$ & $+\mathbf{B}$ & $-\mathbf{B}$ & $+B$ & $-\mathbf{B}$ & $+B$ \\
\hline PMH & $1.42 \mathrm{aB}$ & $2.31 \mathrm{aA}$ & $0.46 \mathrm{aA}$ & $0.53 \mathrm{bA}$ & $0.74 \mathrm{aB}$ & $1.26 \mathrm{aA}$ \\
\hline PMW & $1.31 \mathrm{aA}$ & $1.03 \mathrm{bA}$ & $0.31 \mathrm{abA}$ & $0.26 \mathrm{cA}$ & $0.59 \mathrm{abA}$ & $0.48 \mathrm{bA}$ \\
\hline ORG & $0.86 \mathrm{abB}$ & $2.83 \mathrm{aA}$ & $0.18 \mathrm{bB}$ & $0.80 \mathrm{aA}$ & $0.36 \mathrm{abB}$ & $1.38 \mathrm{aA}$ \\
\hline CBM & $1.13 \mathrm{abA}$ & $0.85 \mathrm{bA}$ & $0.24 \mathrm{abA}$ & $0.25 \mathrm{cA}$ & $0.60 \mathrm{abA}$ & $0.48 \mathrm{bA}$ \\
\hline Soil & $0.53 \mathrm{bA}$ & $0.66 \mathrm{bA}$ & $0.13 \mathrm{bA}$ & $0.16 \mathrm{cA}$ & $0.32 \mathrm{bA}$ & $0.43 \mathrm{bA}$ \\
\hline C.V. (\%) & & & & & & \\
\hline
\end{tabular}

PMH: poultry manure with rice husk base; PMW: poultry manure with wood shavings base; ORG: Organosuper; CBM: castor bean meal. Averages followed by lower case letters equal, in the columns, for residues and upper case in the lines, for bokashi, do not differ between them, by Tukey's test and Student's t-test, respectively, at $5 \%$. 
The chemical composition of the substrates can influence the root mass gain and consequently the dry mass of the plants (Cruz et al., 2016), as observed in this study. In a study on the agronomic response of cultivars of Mangifera indica L. to organic and mineral fertilizers, Peralta-Antonio et al. (2014) showed that the highest yields were obtained when $10 \mathrm{tha}^{-1}$ of poultry manure, or bokashi, were used.

A further beneficial effect associated with the addition of organic residues such as poultry manure with rice husk base or Organosuper was the increased availability of phosphorus (Table 2), especially as the soil used in the experiment was Dystroferric Red Latosol with clay texture. Phosphorus is strongly adsorbed to oxides of iron, aluminum, and clay minerals in Cerrado soils, which causes nutrient deficiency. Thus, the addition of these residues increased nutrient availability (Souza et al., 2013).

Similar results regarding organic residues were reported in a study on the growth of Eugenia pyriformis Cambess. in different substrates. Scalon \& Jeromine (2013) observed higher dry leaf mass $\left(0.36 \mathrm{~g} \mathrm{plant}^{-1}\right)$ of seedlings in Dystroferric Red
Latosol, sand, and poultry manure (1:1:0.5) and the field capacity was maintained at $100 \%$.

The leaf area ratio or the specific leaf area was not influenced by the factors under investigation. In contrast, the highest leaf mass was influenced only by organic residues, and occurred in plants grown in ORG, differing only from the soil (Table 8). The specific foliar mass reflects the dry mass fraction retained in the plant and leaf area. Thus, as the plant grows, a greater transfer of photoassimilates from the leaves to the other organs (Benincasa, 2003) occurs, and this was observed in this study in the plants grown in the substrate.

The highest DQIs were observed in plants cultivated in PMH and ORG, both with bokashi, and PMW, without bokashi (Table 9). Higher DQIs were observed because the substrates favor the conditions required for the marmelo-do-cerrado to develop and to have greater mass production and growth characteristics, photosynthetic pigments, providing higher quality in the young plants by favored suitable conditions of substrates.

Table 8. Leaf area ratio (LAR), specific leaf area (SLA) and specific foliar mass (SFM) of marmelo-do-cerrado cultivated in pots with soil and organic residues.

\begin{tabular}{|c|c|c|c|}
\hline & LAR & SLA & SFM \\
\hline Organic residues & \multicolumn{2}{|c|}{$\left(\mathrm{cm}^{2} \mathrm{~g}^{-1}\right)$} & $\left(\mathrm{g} \mathrm{cm}^{-2}\right)$ \\
\hline Poultry manure with rice husk base & $58.56 \mathrm{a}$ & $106.45 \mathrm{a}$ & $0.0100 \mathrm{ab}$ \\
\hline Poultry manure with wood shavings base & 59.69 a & $101.43 \mathrm{a}$ & $0.0102 \mathrm{ab}$ \\
\hline Organosuper ${ }^{\circledast}$ & $48.52 \mathrm{a}$ & 82.09 a & $0.0122 \mathrm{a}$ \\
\hline Castor bean meal & 50.82 a & 90.87 a & $0.0110 \mathrm{ab}$ \\
\hline Soil & $58.60 \mathrm{a}$ & $110.52 \mathrm{a}$ & $0.0094 \mathrm{~b}$ \\
\hline C.V. $(\%)$ & 20.67 & 20.73 & 15.89 \\
\hline
\end{tabular}

Averages followed by equal letters in the columns do not differ by Tukey's test for organic residues at $5 \%$.

Table 9. Dickson quality index of marmelo-do-cerrado with organic residues and bokashi (B).

\begin{tabular}{|c|c|c|}
\hline Organic residue & $-\mathbf{B}$ & $+\mathbf{B}$ \\
\hline Poultry manure with rice husk base & $1.23 \mathrm{aB}$ & $1.64 \mathrm{aA}$ \\
\hline Poultry manure with wood shavings base & $1.25 \mathrm{aA}$ & $0.46 \mathrm{bB}$ \\
\hline Organosuper & $0.68 \mathrm{abB}$ & $1.74 \mathrm{aA}$ \\
\hline Castor bean meal & $0.82 \mathrm{abA}$ & $0.78 \mathrm{bA}$ \\
\hline Soil & $0.44 \mathrm{bA}$ & $0.33 \mathrm{bA}$ \\
\hline C.V. $(\%)$ & 29.45 & \\
\hline
\end{tabular}

Averages followed by lower case letters equal, in the columns, for residues, and upper case in the lines, for bokashi, do not differ between them, by Tukey's test and Student's t, respectively, at $5 \%$.
The addition of poultry manure to the substrate also increased the quality of Ocimum basilicum L. seedlings cultivated in Dystroferric Red Latosol (Souza et al., 2011). The DQI is a fundamental parameter in the evaluation of the quality of the seedlings as it combines biometric and mass production increase characteristics. The higher the DQI the better, because there is stability in the growth in the plants.

Evaluation of this parameter is important for verifying whether the seedlings are sufficiently developed to survive after transplanting to the field (Silva et al., 2012), allowing the selection of the most vigorous plants according to the substrate composition. The addition of poultry manure with rice husk base and Organosuper ${ }^{\circ}$, both with bokashi, improved DQI values. In general, it was observed that the use of poultry manure or Organosuper ${ }^{\circ}$ is a viable practice for native species such as the slow-growing marmelo-do-cerrado. 


\section{CONCLUSION}

Marmelo-do-cerrado responds positively to the addition of organic residue in the substrate of the cultivated. After considering the increase in the growth characteristics, photosynthetic pigments and the efficiency of the photosystem II, biomass production, and plant quality, we concluded that the addition of Organosuper ${ }^{\circledR}$ or poultry manure with rice husk base, in association with bokashi in the substrate, can be used for enhancing the initial growth of marmelo-do-cerrado.

\section{ACKNOWLEDGEMENTS}

The authors thank the Foundation for the Development of Education, Science, and Technology of the State of Mato Grosso do Sul (FUNDECT) and the Coordination for the Improvement of Higher Education Personnel (CAPES), for the financial support associated with the development and dissemination of this work, and the National Council for Scientific and Technological Development (CNPq), for granting a research scholarship.

\section{SUBMISSION STATUS}

Received: 11 Oct. 2017

Accepted: 30 June 2018

Associate editor: João Vicente de Figueiredo Latorraca

(1) 0000-0002-5969-5199

\section{CORRESPONDENCE TO Cleberton Correia Santos}

Universidade Federal da Grande Dourados (UFGD), Faculdade de Ciências Agrárias, Rodovia Dourados-Itahum, km 12, CEP 79825-070,

Dourados, MS, Brasil

e-mail: cleber_frs@yahoo.com.br

\section{FINANCIAL SUPPORT}

Conselho Nacional de Desenvolvimento Científico e Tecnológico (CNPq); Coordenação de Aperfeiçoamento de Pessoal de Nível Superior (Capes); Fundação de Apoio ao Desenvolvimento do Ensino, Ciência e Tecnologia do Estado de Mato Grosso do Sul (Fundect).

\section{REFERENCES}

Álvares-Solís JD, Mendonza-Núñes JA, León-Matrinez NS, Castellanos-Albores J, Gutiérrez-Miceli FA. Effect of bokashi and vermicompost leachate on yield and quality of pepper (Capsicum annuum) and onion (Allium cepa) under monoculture and intercropping cultures. Ciencia e Investigación Agraria 2016; 43(2): 243-252. 10.4067/S0718-16202016000200007

Arnon DI. Copper enzymes in isolated chloroplasts: polyphenol oxidases in Beta vulgaris. Plant Physiology 1949; 24(1): 1-15.
Baldotto MA, Baldotto LEB. Initial performance of corn in response to treatment of seeds with humic acids isolated from bokashi. Revista Ceres 2016; 63(1): 62-67. 10.1590/0034-737X201663010009

Benincasa MMP. Análise do crescimento de plantas (noções básicas). Jaboticabal: Funep; 2003.

Bento LF, Dresch DM, Scalon SPQ, Masetto TE. Storage of Alibertia edulis seeds: influence of water content and storage conditions. African Journal Agriculture Research 2016; 11(18): 1646-1655. 10.5897/AJAR2016.10871

Boechat CL, Santos JAG, Accioly AMA. Net mineralization nitrogen and soil chemical with application of organic wastes with "fermented Bokashi compost”. Acta Scientiarum: Agronomy 2013; 35(2):257-284. 10.4025/actasciagron.v35i2.15133

Bolan NS, Szogi AA, Chuasavathi T, Seshadri B, Rothrock MJ, Panneerselvam P. Uses and management of poultry litter. World's Poultry Science Journal 2010; 66(4): 673-698. 10.1017/ S0043933910000656

Calegari L, Martins SV, Busato LC, Silva E, Coutinho R Jr, Gleriani JM. Produção de mudas de espécies arbóreas nativas em viveiro via resgate de plantas jovens. Revista Árvore 2011; 35(1): 41-50. 10.1590/S0100-67622011000100005

Campos MAA, Uchida T. Influência do sombreamento no crescimento de mudas de três espécies amazônicas. Pesquisa Agropecuária Brasileira 2002; 37(3): 281-288. 10.1590/S0100-204X2002000300008

Carnevali TO, Vieira MC, Luciano AT, Gonçalves WV, Rodrigues WB, Ramos MBM. Crescimento inicial de Campomanesia xanthocarpa O. Berg sob diferentes composições de substratos. Revista Brasileira de Plantas Medicinais 2015; 17(2): 316-323. 10.1590/1983-084X/12_080

Cruz FRS, Andrade LA, Feitosa RC. Produção de mudas de umbuzeiro (Spondias tuberosa Arruda Camara) em diferentes substratos e tamanho de recipientes. Ciência Florestal 2016; 26(1):68-80. 10.5902/1980509821092

Dickson A, Leaf AL, Hosner JF. Quality appraisal of white spruce and white pine seedling stock in nurseries. Forestry Chronicle 1960; 36(1):10-13. 10.5558/tfc36010-1

Eguchi ES, Cecato U, Muniz AS, Mari GC, Murano RAC, Sousa Neto EL. Physical and chemical changes in soil fertilized with poultry manure with and without chiseling. Revista Brasileira de Engenharia Agrícola e Ambiental 2016; 20(4): 316-321. 10.1590/1807-1929/ agriambi.v20n4p316-321

Ghorbani R, Wilcockson S, Koocheki A, Leifert C. Soil management for sustainable crop disease control: a review. Environmental Chemistry Letter 2008; 6(3): 149-162. 10.1007/s10311-008-0147-0

González-Sanpedro MC, Le Toan T, Moreno J, Kergoat L, Rubio E. Seasonal variations of leaf area index of agricultural fields retrieved from Lands at data. Remote Sensing of Environment 2008; 112(3): 810-824. 10.1016/j.rse.2007.06.018

Instituto Brasileiro de Geografia e Estatística - IBGE. Indicadores agropecuários 2015 [Internet]. 2015 [cited 2016 Nov 10]. Available from: http://www.ibge.gov.br

Kiehl EJ. Adubação orgânica: 500 perguntas e respostas. Piracicaba: Degaspari; 2008.

Leles PSS, Abaurre GW, Alonso JM, Nascimento DF, Lisboa AC. Crescimento de espécies arbóreas sob diferentes espaçamentos 
em plantio de recomposição vegetal. Scientia Forestalis 2011; 39(90): 231-239.

Lichtenthaler HK, Buschmann C. Chlorophylls and carotenoids: measurement and characterization by UV-VIS spectroscopy. Current Protocols in Food Analytical Chemistry 2011; 1(1): F4.3.1-F4.3.8. 10.1002/0471142913.faf0403s01

Lorenzi H, Bacher L, Lacerda M, Sartori S. Frutas brasileiras e exóticas cultivadas (de consumo in natura). São Paulo: Instituto Plantarum de Estudos da Flora; 2006.

Mangiori VRL, Tavares Filho J. Disposição de resíduos sólidos no solo: efeitos nos atributos físicos, químicos e na matéria orgânica. Semina: Ciências Agrárias 2015; 36(2): 747-764. 10.5433/1679-0359.2015v36n2p747

Marques MCS, Hamerski L, Garcez FR, Tieppo C, Vasconcelos $\mathrm{M}$, Torres-Santos EC et al. In vitro biological screening and evaluation of free radical scavenging activities of medicinal plants from the Brazilian cerrado. Journal of Medicinal Plants Research 2013; 7(15): 957-962. 10.5897/JMPR12.882

Mosaddeghi MR, Mahboubi AA, Safadoust A. Short-term effects of tillage and manure on some soil physical properties and maize root growth in a sandy loam soil in western Iran. Soil Tillage Research 2009; 104(1): 173-179. 10.1016/j.still.2008.10.011

Murchie EH, Lawson T. Chlorophyll fluorescence analyses: a guide to good practice and understanding some new applications. Journal Experimental Botany 2013; 64(13): 3983-3998. 10.1093/jxb/ert208

Oliveira JC, Vieira ICG, Almeida AS, Silva CA Jr. Floristic and structural status of forests in permanent preservation areas of Moju river basin, Amazon region. Brazilian Journal of Biology 2016; 76(4): 912-927. 10.1590/1519-6984.04415

Peixoto Filho J, Freire MBGS, Freire FJ, Miranda MFA, Pessoa LGM, Kamimura KM. Produtividade de alface com doses de esterco de frango, bovino e ovino em cultivos sucessivos. Revista Brasileira de Engenharia Agrícola e Ambiental 2013; 17(4): 419424. 10.1590/S1415-43662013000400010

Peralta-Antonio N, Rebolledo-Martínez A, Becerril-Román AE, Jaén-Contreras D, Angel-Pérez AL. Response to organic fertilization in mango cultivars: manila, tommy atkins and ataulfo. Journal of Soil Science and Plant Nutrition 2014; 14(3): 668-700. 10.4067/S0718-95162014005000055

Rieder A. Plants used for diabetes in the transition zone of Platinum and Amazon Hydrographic Basins, southwest portion of Mato Grosso, Brazil. Planta Medica 2013; 79(13): PF8. 10.1055/s0033-1352065

Rogeri DA, Ernani PR, Mantovani A, Lourenço KS. Composition of poultry litter in Southern Brazil. Revista Brasileira de Ciência do Solo 2016; 40: e0140697. 10.1590/18069657rbcs20140697
Santos HG, Jacomine PKT, Anjos LHC, Oliveira VA, Coelho MR, Lumbreras JF et al. Sistema brasileiro de classificação de solos. 3rd ed. Rio de Janeiro: Embrapa Solos; 2013.

Scalon SPQ, Jeromine TS. Substratos e níveis de água no potencial germinativo de sementes de uvaia. Revista Árvore 2013; 37(1):49-58. 10.1590/S0100-67622013000100006

Silva FC. Manual de análises químicas do solo, plantas e fertilizantes. 2nd ed. Brasília, DF: Embrapa Informação Tecnológica; 2009.

Silva RF, Saidelles FLF, Kemerich PDC, Steffen RB, Swarowsky A, Silva AS. Crescimento e qualidade de mudas de timbó e dedaleiro cultivadas em solo contaminado por cobre. Revista Brasileira de Engenharia Agrícola e Ambiental 2012; 16(8): 881-886. 10.1590/ S1415-43662012000800010

Silva VC, Giannini MJSM, Carbone V, Piacente S, Pizza C, Bolzani VS et al. New antifungal terpenoid glycosides from Alibertia edulis (Rubiaceae). Helvetica Chimical Acta 2008; 91(7):1355-1362. 10.1002/hlca.200890147

Souza NH, Carnevali TO, Ramos DD, Scalon SPQ, Marchetti ME, Vieira MC. Produção de mudas de manjericão (Ocimum basilicum L.) em diferentes substratos e luminosidade. Revista Brasileira de Plantas Medicinais 2011; 13(3): 276-281. 10.1590/ S1516-05722011000300005

Souza NH, Marchetti ME, Carnevali TO, Ramos DD, Scalon SPQ, Silva EF. Estudo nutricional da canafístula (I): crescimento e qualidade das mudas em resposta a adubação com nitrogênio e fósforo. Revista Árvore 2013; 37(4): 717-724. 10.1590/S010067622013000400015

Streit NM, Canterle LP, Canto MW, Hecktheur LHH. The chlorophylls. Ciência Rural 2005; 35(3): 748-755. 10.1590/S010384782005000300043

Taiz L, Zeiger E. Fisiologia vegetal. 5th ed. Porto Alegre: Artmed; 2013.

Valadão FCA, Maas KDB, Weber OLS, Valadão DD Jr, Silva TJ. Variação nos atributos do solo em sistema de manejo com adição de cama de frango. Revista Brasileira de Ciência do Solo 2011;35(6): 2073-2082. 10.1590/S0100-06832011000600022

Veigas IJM, Sousa GO, Silva AF, Carvalho JG, Lima MM. Composição mineral e sintomas visuais de deficiência em plantas de pimenta longa (Piper hispidinervum C. DC.). Acta Amazonica 2013; 43(1):43-50. 10.1590/S0044-59672013000100006

Vieira MC, Ramos MBM, Heredia Zárate NA, Luciano AT, Gonçalves WV, Rodrigues WB et al. Adubação fosfatada associada à cama de frango e sua influência na produtividade e no teor de flavonoides da marcela (Achyrocline satureioides (Lam.) DC.) em duas épocas de colheita. Revista Brasileira de Plantas Medicinais 2015; 17(2): 246-253. 10.1590/1983-084X/13_042 